\title{
非線形要素を考慮した機械構造変更予測法* \\ モーダル解析の応用法
}

\author{
大久保信 行** 望月貴 裕***
}

Development of Structural Modification Method

in Consideration of Non-linear Elements

Nobuyuki Oкuво and Takahiro Mochizuki

\begin{abstract}
The modal synthesis method for mass, stiffness or damping structural modification is so extended as to take into consideration of non-linear elements. First the experimental modal analysis is used to characterize the non-linear elements, like rubber mounts, engine mounts, etc. with respect to the frequency of external force but also to the acceleration level. Then a new method of structural modification developed can predict when the original structure is modified by non-linear elements. In addition to numerical examples, the method is applied to an actual simple structure.
\end{abstract}

Key words : modal analysis, non-linear element, structural modification

\section{1. はじめに}

現在の機械設計においては，機械の高性能化の要求 に伴い機械の動特性を把握することが重要となり，こ の動特性を把握する手法の一つである実験的モーダル 解析が㳎く利扭されている.さらに最近では，モーダ ル解析結果に基づき, 構造物の構造変更後の動特性を 予測寸る手法が開発され実用化されている(1)2.

このように構造変更後の動特性を予測できることは 構造物の設計段階において動特性改善のための試作回 数を減らすことが可能となり, 非常に有効である.

しかし構造物の動特性の改善要求がさらに高度で複 雑, 寸なわち広域の周波数や振幅にわたり動特性を改 善しなければならなくなった今日では，構造物の一部 に非線形要素を取り入れ，その改善要求に対応しょう としている. そのため構造変更後のばねおよび減衰特 性が線形であることを前提としている従来の手法では 周波数や振幅依存性を有する非線形要素を考慮しなが ら構造変更後の動特性を予測することは困難である.

このために，非線形振動理論に基づき適当な非線形 モデルを仮走した場合の予測法もいくつか発表されて はいるが(3)4, この非線形モデル化が実際の非線形要素

* 原稿受付 芿和 62 年 6 月 11 日。昭和 62 年度精密工学会 春季大会学術講演会 (昭和 62 年 3 月 28 日) にて発表

** 正: 全員 如央大学理1学部(東京都文京区春日1-1327)

*** 学生会員 中央大学。大学院
を適切に表現できているかは明らかではなかった。 そこで本論文では，実験的モーダル解析を利用し， まず対象の非線形要素の非線形性を定性的, 定量的に 簡便に求める実験方法を考案し，この結果に基づき， 従来の構造変更予測法を拡張し, モーダルパラメータ (固有振動数, 減衰比, 振動モード)によって記述され た全体構造物の一部をその非線形要素により，構造変 更した際の動特性変化の予測法について述べる.さら に本手法の数值シミュレーションおよび実際の構造物 への適用例を示し，その有効性を確認する。なお，対 象とする実際の非線形要素としては, 最近の音響機器, 情報機器等の防振に用いられるゴムばねや, 自動車用 エンジンのマウントを想定している.

\section{2. 非線形要素の非線形性の定量化}

構造変更後の動特性を予測するためには構造変更部 分の要素の特性，例えば，ばね特性および減衰特性を 知る必要がある。これらの特性を求めるため, 本研究 では変更する非線形要素の一端に適当な質量を付加 し，他端を固定した 1 自由度系として測定した伝達関 数より，その系の非線形ばね扝よび減衰特性を定量化 する方法を採用する.

質量 $M$ と，周波数 $\omega$ およびその要素の両端間の相 対変位 $X$ の関数と仮定した非線形ばね $K_{\mathrm{NL}}(\omega, X)$ と 非線形減衰 $C_{\mathrm{NL}}(\omega, X)$ から成る 1 自由度系の外力 $F$ に対するコンプライアンス伝達関数 $(X / F)$ は, 周波 

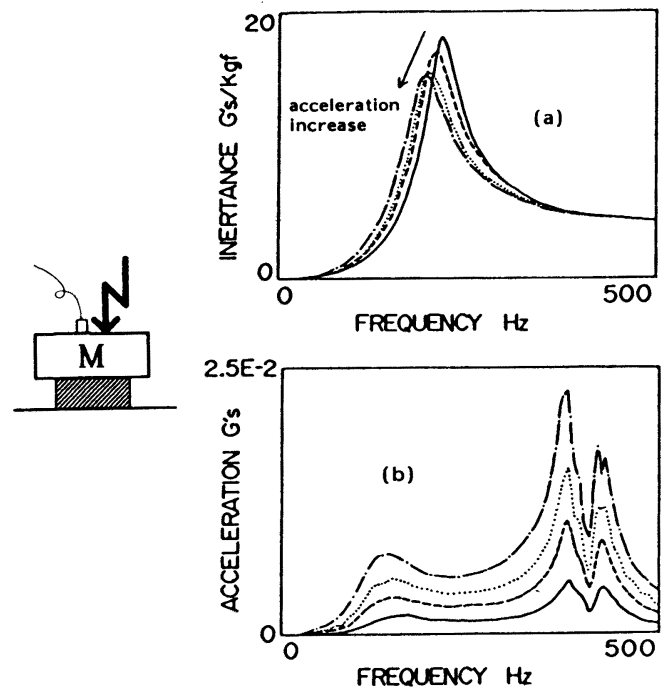

Fig. 1 Frequency response functions (FRF) of nonlinear element (weight $280 \mathrm{gf}$ )

数領域に捛いて次のように表される.

$$
\frac{X(\omega)}{F(\omega)}=\frac{1}{-\omega^{2} M+\mathrm{j} \omega C_{\mathrm{NL}}(\omega, X)+K_{\mathrm{NL}}(\omega, X)}
$$

式 (1) を動剛性 $(F / X)$ に変形し，その実数部をと れば式 (2) が導かれる.

$$
\operatorname{Re}\left(\frac{F(\omega)}{X(\omega)}\right)=-\omega^{2} M+K_{\mathrm{NL}}(\omega, X)
$$

式 (2) から分かるように質量 $M$ が既知で動剛性が 測定されれば非線形ばね $K_{\mathrm{NL}}(\omega, X)$ が求められる。 た式 (1) を機械インピーダンス $(F / V)$ に変形し，そ の実数部をとれば式 (3) が導かれる.

$$
\operatorname{Re}\left(\frac{F(\omega)}{V(\omega)}\right)=C_{\mathrm{NL}}(\omega, X)
$$

式 (3) から分かるように, 機械インピーダンスが測 定されれば非線形減衰 $C_{\mathrm{NL}}(\omega, X)$ が求められる.

以上の手法を実際のゴムばね（直径 $29 \mathrm{~mm}$, 厚さ 12 $\mathrm{mm}$, 重さ $8 \mathrm{gf}$ ) に適用した。ゴムばねに適当な質量 （重さ $280 \mathrm{gf}, 550 \mathrm{gf}, 930 \mathrm{gf}$ )をのせ 1 自由度系とし て正弦波掃引で加振力を変化させ，それぞれのイナー タンス伝達関数 $(A / F)$ を測定した（図 $1(\mathrm{a}))$. また 図中には，その際のゴムばねの両端の相対加速度（測 定に扔いては加速度計を用いているので，相対変位の 代わりとした）を（b）に示す. 図中の実線, 破線, 点 線, 一点鎖線は加振力の弱い順に対応している.

この図から分かるように相対加速度の増大に従って 固有振動数が下がり, 振幅も減少している.すなわち このゴムば齐が相対加速度に依存する非線形性を有す
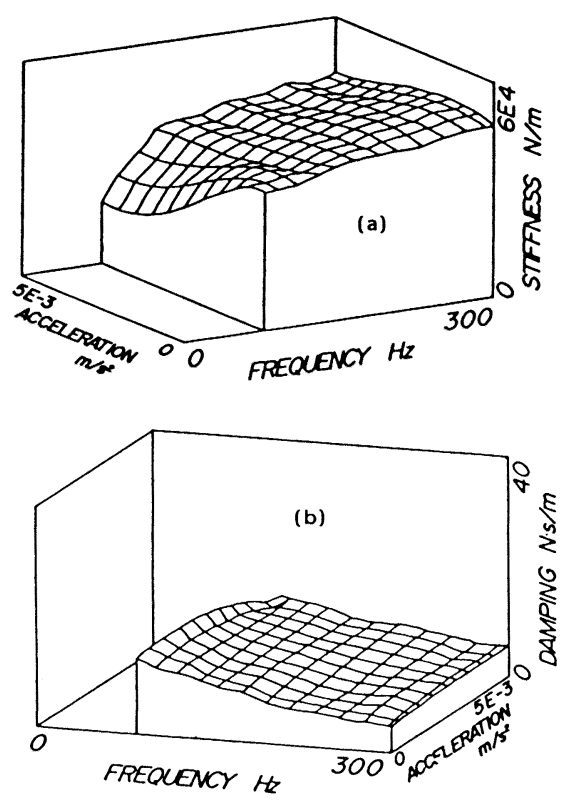

Fig. 2 Identified non-linear stiffness and damping of the element

ることが推測される.

そして先の非線形性の定量化の理論に従い, 実際に 測定した伝達関数とその際の相対加速度より非線形ば ね定数と減衰定数を各周波数について相対加速度の関 数として多項式近似し，滑らかな曲線とした。なお， ここではゴムばねにのせた 3 つの重さの異なる質量に ついてそれぞれ測定されたイナータンス伝達関数すべ てのデータを使用している.

図 2 にこのようにして得られたゴムばねの特性を 3 次元表示する。図（a）から分かるよらに，この特性を 表す面は, 線形の場合には平面, 寸なわち周波数, 相 対加速度に依存しないのに比し，曲面をなしており， 周波数と相対加速度に依存する非線形性を有すること が分かる.さらに詳しく観察すると周波数が高くなる につれてばね定数が大きくなり, 相対加速度の増大と ともにば坟定数が小さくなることが分かる。このばね 定数の相対加速度依存性が図 1 亿示す伝達関数の固有 振動数を移行させている. 同様にして求めた非線形減 衰定数も図中 (b) に示す.

なお，ここで仮定した非線形の種類としては，その 非線形ば就および減衰特性が周波数および相対加速度 の関数で表現できるものであり，すきまのように非連 続な非線形には適していない。亩た, 非線形の程度に ついても, 本文中以外の非線形要素に適用した実例か ら，極端な場合以外は実用可能であると経験されてい る. 


\section{3. 非線形要素を考慮した構造変更予測法 の理論}

まず構造変更の対象となる機械構造物の運動方程式 は物理座標系で式 (4) となる。

$$
[M]\{\ddot{X}\}+[C]\{\dot{X}\}+[K]\{X\}=\{F\}
$$
ただし，
$[M]$ : 線形質量マトリクス
$[C]$ : 線形減衰マトリクス
$[K]$ : 線形剛性マトリクス

ここで, 式 (4)の $X$ はモーダル解析を行う際の機械 構造物の測定点に対応している.いま, 測定点数を $m$ としモーダル解析によって $n$ 組のモーダルパラメー タが抽出されたとする。このモーダルパラメータの組 の数は測定点数よりも少ないことが通常である。また 対象の機械構造物が比例粘性減衰であると仮定すると 各振動モードを列とする振動モードマトリクス 用いることにより，マトリクスの大きさが $m \times m$ の式 (4) から $n \times n$ のモダル座標系の運動方程式（5）が 導かれる.

$$
\lceil m\rfloor\{\ddot{z}\}+\lceil c\rfloor\{\dot{z}\}+\lceil k\rfloor\{z\}=[\phi]^{\mathrm{T}}\{F\}
$$
ただし，

$[\phi]^{\mathrm{T}}[M][\phi]=\lceil m\rfloor:$ モード等価質量

$[\phi]^{\top}[C][\phi]=\lceil c\rfloor:$ モード等価減衰

$[\phi]^{\mathrm{T}}[K][\phi]=\lceil k\rfloor:$ モード等価剛性

$$
\{z\}: \text { モード座標 }
$$

さて，対象の機械構造物の一部を非線形ばね $K_{\mathrm{NL}}$ $(\omega, X)$ と非線形減衰 $C_{\mathrm{NL}}(\omega, X)$ によって表現される 非線形要素により構造変更する場合を考える。構造変 更後も比例粘性減衰》仮定が近似的に成り立つとする と, 式 (5) から式 (6) が導かれる。

$\lceil m\rfloor\{\ddot{z}\}+\lceil c\rfloor\{\dot{z}\}+\left(-[\phi]^{\mathrm{T}}\left[C_{\mathrm{L}}\right][\phi]+[\phi]^{\mathrm{T}}\left[C_{\mathrm{NL}}\right][\phi]\right)\{\dot{z}\}$ $+\lceil k\rfloor\{z\}+\left(-[\phi]^{\mathrm{T}}\left[K_{\mathrm{L}}\right][\phi]+[\phi]^{\mathrm{T}}\left[K_{\mathrm{NL}}\right][\phi]\right)\{z\}$ $=[\phi]^{\mathrm{T}}\{F\}$ ただし，

$C_{\mathrm{L}}:$ 構造変更部のもとの減衰特性

$C_{\mathrm{NL}}$ : 構造変更部の構造変更後の減衰特性

$K_{\mathrm{L}}$ : 構造変更部のもとのばね特性

$K_{\mathrm{NL}}$ : 構造变更部の構造変更後のばね特性

各周波数 $\omega$ について式 (6)の両辺が等しくなるよ らに非線形ば权 $K_{\mathrm{NL}}(\omega, X)$ と非線形減衰 $C_{\mathrm{NL}}(\omega, X)$ を決定し，式 (6) を固有値解析することにより構造変 更後の固有振動数と振動モードが算出される.

図 3 に非線形要素を考慮した機械構造変更予測法に よる機械構造物の構造変更後の動特性予測プログラム の流れを示す．本プログラムは, 構造変更部の構造変

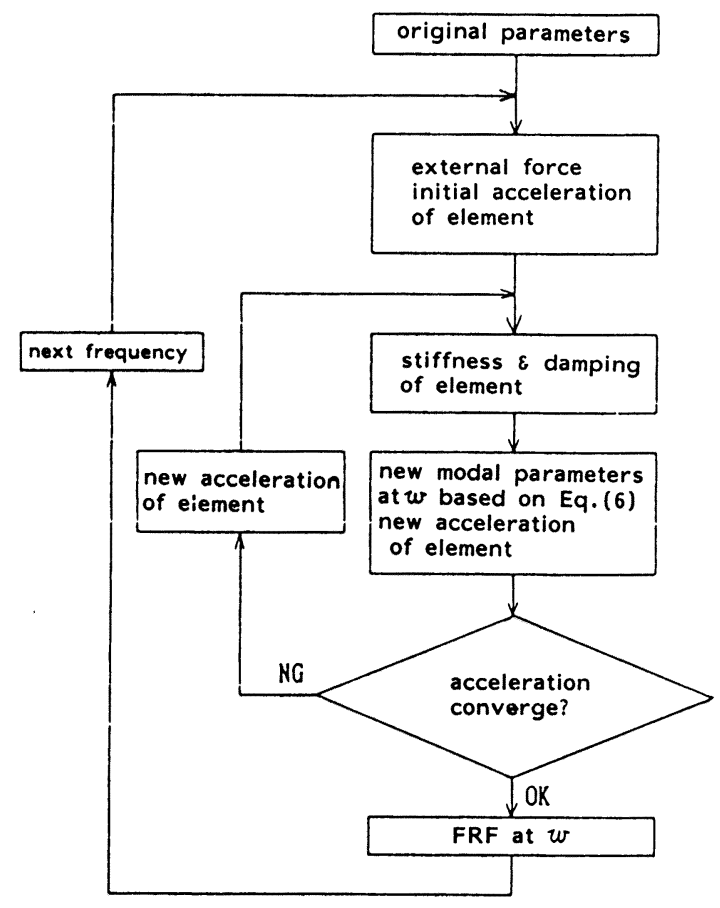

Fig. 3 Flow chart of proposed structural modification method

更前のモーダルパラメータ, 構造変更部の構造変更前 と構造変更後のばね特性および減衰特性, そして周波 数の関数とした外力が入力データとして必要である. これらの入力データをもとに，まず周波数について構 造変更部の初期相対加速度を計算し, 構造変更部のば ねと減衰の值を計算する。 また外力の值も決定する. 次に式 (6) を固有值計算することにより周波数 $\omega$ に 固有の構造変更後のモーダルパラメータが得られる.

ここで, この構造変更後の新しいモーダルパラメータ は他の周波数では異なることに注意する.

さらに新しく得られたモーダルパラメータをもとに 応答点の加速度を計算し, 前回に計算した応答点の加 速度と比較する. 比較した結果, 応答点の加速度が一 定值に収束しない場合には構造変更部のばねと減衰の 値を再度計算し，一連の計算を繰り返す。そして応答 点の加速度が十分に収束した時, 周波数 $\omega$ におけるイ ナータンス伝達関数を決定し, 次の周波数についても 同様にイナータンス伝達関数を決定する.

\section{4. 数值シミュレーションによる本手法の 有効性確認}

本手法で実構造物の構造変更後の動特性を予測する 前に, 3 自由度数学モデルに適用し本手法の有効性を 数值シミュレーションにより確認する. 


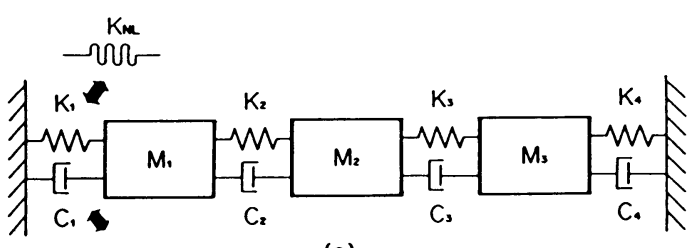

(a)
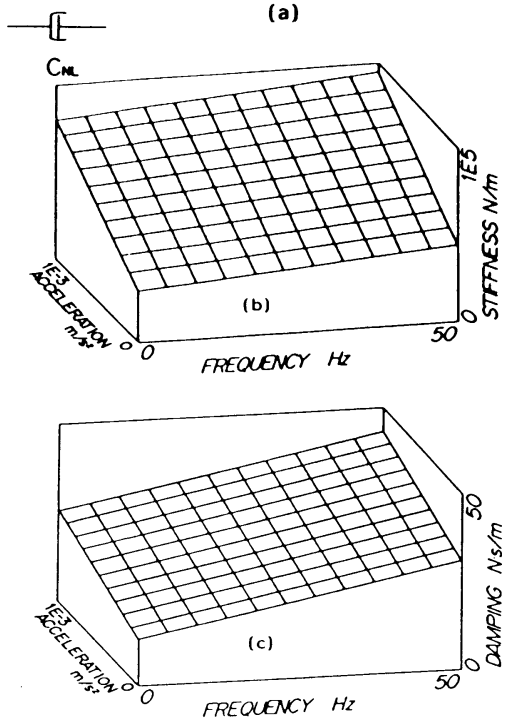

Fig. 4 Numerical simulation for 3-dof model

図 4 に示すように構造変更前は線形 3 自由度系を仮 定する. 構造変更部は図のようにばね $K_{1}$ と減衰 $C_{1}$ で あり，これらを図中 (b)，(c)に示すよらな周波数と相 対加速度の関数である非線形ばね $K_{\mathrm{NL}}$ と非線形減衰 $C_{\mathrm{NL}}$ に交換した. この 3 自由度系の運動方程式を固有 值計算し，3 組のモーダルパラメータを得た。

構造変更後の動特性の予測は 2 通り行った. 1 番目 は 3 自由度系の運動方程式を固有值計算して得た 3 組 のモーダルパラメータをすべて使った純数学的なもの である．ところで実験的モーダル解析を実構造物に適 用して得られるモーダルパラメータの組はその構造物 自体が持つモーダルパラメータの組より少ない.そこ で, 数值シミュレーション時でもこの条件に近くなる ように 3 組のモーダルパラメータのらち低次 2 組の モーダルパラメータを使用して構造変更後の動特性を 予測した。これにより振動モードを用い運動方程式を 縮小して構造変更後の動特性を予測するため，縮小操 作による予測值への影響を見ることができる。

図 5 に $\mathrm{M}_{1}$ を加振し $\mathrm{M}_{1}$ を応答としたときのイナー タンス伝達関数を示す。なた表 1 にこれらの固有振動 数と振幅を示す。図の点線は構造変更前の 3 自由度系 の伝達関数を示す．実線は構造変更後のばねと減衰の 値を物理座標系の運動方程式に代入し，この運動方程

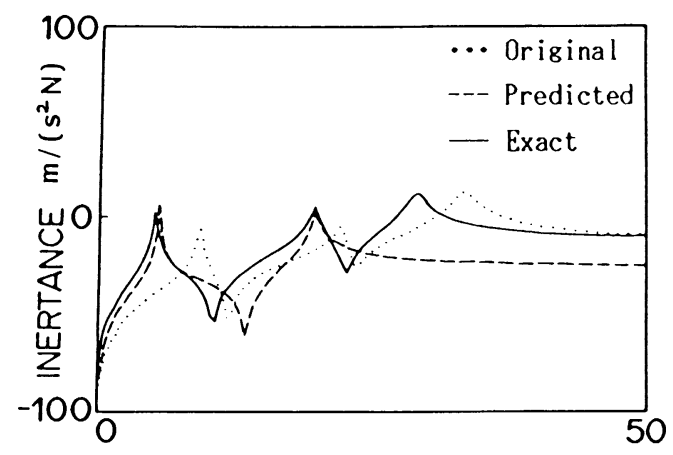

FREQUENCY $\mathrm{Hz}$

Fig. 5 Predicted FRF of 3-dof model due to structural modification

Table 1 Comparison of predicted and exact natural frequencies and amplitudes

\begin{tabular}{c|r|r|r|r|r|r}
\hline & \multicolumn{2}{|c|}{ Exact } & \multicolumn{2}{c|}{$\begin{array}{c}\text { Predicted } \\
\text { 3 Modes }\end{array}$} & \multicolumn{2}{c}{$\begin{array}{c}\text { Predicted } \\
\text { 2 Modes }\end{array}$} \\
\hline Mode $\#$ & \multicolumn{1}{|c|}{ Freq. } & Amp. & Freq. & Amp. & Freq. & Amp. \\
\hline 1 & 5.91 & 1.29 & 5.91 & 1.29 & 6.30 & 1.61 \\
2 & 20.50 & 1.72 & 20.50 & 1.71 & 20.50 & 1.08 \\
3 & 29.50 & 3.63 & 29.50 & 3.63 & & - \\
\hline
\end{tabular}

Freq. ; $\mathrm{Hz}, \mathrm{Amp} . ; \mathrm{m} /\left(\mathrm{s}^{2} \mathrm{~N}\right)$

式から直接に伝達関数を決定したものでこれを正解値 とする. 3 組のモーダルパラメータすべてを使朋し本 手法により構造変更後の動特性を予測し得られた伝達 関数は図の実線と重なっている.

また破線が低次 2 組のモーダルパラメータを使用し 本手法により予測した構造変更後の伝達関数である. 図の破線から分かるように低次 2 組のモーダルパラ メータを使用した場合には構造变更後の動特性も低次

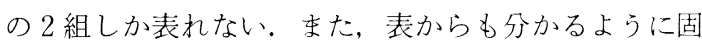
有振動数とその振幅に抏いて低次 2 組のモーダルハラ メータしか使用しない場合には，3 次モードの影響が 考慮できないことと振動モードによる縮小操作上の䛊 差により正解值とのずれが認められるが実用上は十分 な精度である。

\section{5. 簡単な実構造物への適用}

図 6 に示すようにロ型フレームの両端に同じ特性の ゴムばねを取り付け，ゴムばねの両端を固定支持した 構造物に対し本手法を適用した。

加振方法は正弦波掃引を行い，応答検出には加速度 計を使用し測定点は加振方向に 10 点とした。測定周波 数範囲は0〜300 Hz で構造変更前に測定した伝達関 数を解析した結果 3 組のモーダルパラメータが抽出さ れた。図 7 の点線に示すイナータンス伝達関数は, 図 


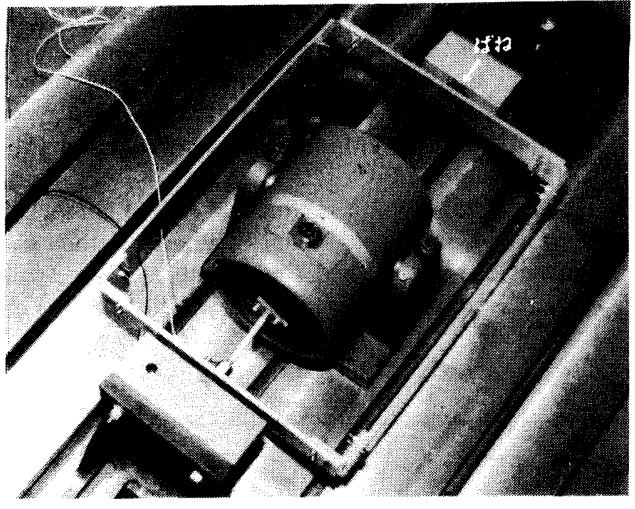

Fig. 6 Frame structure under test

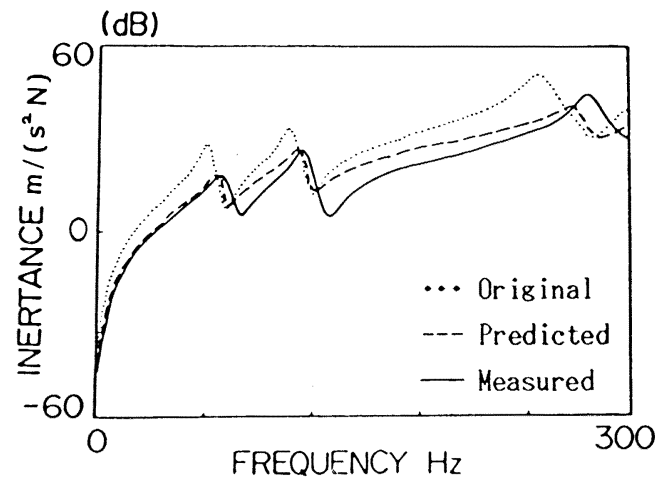

Fig. 7 Predicted and measured FRFs of frame due to structural modification

6 に示すようにゴムば权を取り付けたフレームの内側 の部分を加振し，同じ部分を応答点としたものである.

構造変更は口型フレームの両端の線形ばねを, 図 2 に示した特性をもつゴムばねに2つとも交換した。本 手法により構造変更後の予測した伝達関数の精度を判 断するために実際に構造変更した構造物の伝達関数も 測定した。加振少法や心答検出方法は構造変更前と同 様に正泫波掃引加振を行い加速度計によって応答を検

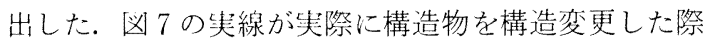
のイナータンス伝澾関数である.

一方，本手法をこの構造変更に適用した，入才デー 夕は, 構造変更前に実際に測定, 解析して得られた 3 組のモーダルパラメータと前述の理論に基づき, あら かじめ測走して抢いた構造変更部の構造変更前のゴム ばねの特性および構造変更後のゴムばねの特性と構造 変更後に伝達関数を測起した際の加振力のスペクトル

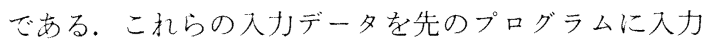
して子測した構造変更後のイナータンス伝達関数を図 7の点線に示す。また表 2 に実際に構造変更し測定し た固有振動数と本手法により構造変更後の予測した伝
Table 2 Comparison of predicted and measured natural frequencies

\begin{tabular}{c|c|c|c}
\hline Mode $\#$ & $\begin{array}{c}\text { Measured } \\
\mathrm{Hz}\end{array}$ & $\begin{array}{c}\text { Predicted } \\
\mathrm{Hz}\end{array}$ & $\begin{array}{c}\text { Error } \\
\%\end{array}$ \\
\hline 1 & 72.96 & 70.10 & -3.9 \\
2 & 117.82 & 114.20 & -3.1 \\
3 & 278.63 & 267.70 & -3.9 \\
\hline
\end{tabular}

Table 3 MAC of predicted and measured mode shapes

\begin{tabular}{|c|c|c|c|c|}
\hline & \multicolumn{3}{|c|}{ Predicted modes } \\
\hline & & 1 & 2 & 3 \\
\hline \multirow{3}{*}{\multicolumn{2}{|c|}{ 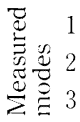 }} & 0.96239 & 0.01726 & 0.32057 \\
\hline & & 0.02601 & $\underline{0.66641}$ & 0.02869 \\
\hline & & 0.28410 & 0.10590 & 0.53357 \\
\hline
\end{tabular}

達関数より求めた固有振動数の比較を示す.

表から分かるように実際に構造变更し測定した固有 振動数と本手法により予測した伝達関数より求めた固 有振動数の誤差は，3モードとも $4 \%$ 弱であり精度よ く予測できている。 また図 7 より振幅面からも特に 1 次モード，2次モードは精度よく予測されていること が分かる.

また，実際に構造変更し測定した伝達関数を解析し て得られた振動モードと本手法により予測した構造変 更後の振動モードの相関を表 3 に示す. この振動モー ドの相関は, MAC (Modal Assurance Criterion)と 呼ばれるもので ${ }^{2)}$ そのの値は $0 \sim 1$ の間をとり，0の場 合は無相関で 1 の場合は振動モードが一致しているこ とを表す. 表より, 実際に測定, 解析して得た振動モー ドと本手法によって予測した振動モードの対応がとれ ていることが分かる. 李た表において高次の対角の MACの值が低いのは, 本手法による予測で 4 次モー ド以上の影響を考慮していないためと考えられる。

また，ここでは構造変更後も比例粘性減衰を近似的 に仮定しているため，変更前に比べ外力のレベルが大 きく異なる場合の予測に関しては䛊差が大きくなると 考えられる.

以上のことから本手法が実構造物においても構造変 更後の動特性を子測する場合にも有効的であることが 確かめられた。

\section{6. 結 論}

以上，本論文により下記のことが結論づけられる。

（1）非線形ばね㧍よび非線形減衰を实際に測定し た伝達関数より定量化する方法を確立した。

（2）非線形要素を考慮した機械構造変更予測法を 数学モデルに適用し，その有効性を確認した。 
（3）本手法を簡単な実構造物に適用し，構造変更後 の動特性を精度よく予測できることを確認した.

（4）構造物の設計段階において, 本手法を用いるこ とにより非線形要素を考慮しながら構造変更後の 動特性を予測することができるため構造物の最適 な構造変更設計に有効である.

\section{参 考 文 献}

1) 大久保信行：機械のモーダルアナリシス, 中央大学出版部
(1982).

2) D. J. Ewins: Modal Testing: Theory and Practice, Research Studies Press, England, (1984).

3) H. Ito, E. Kobayashi \& S. Murai : Non-linear System Simulation by the Modal Method, Proc. 2nd IMAC, Vol. 1, (1984) 528.

4) H. Zui, E. Imanishi, Y. Hamazaki \& T. Fujikawa : An Improved Component Modal Synthesis Method Using Retransformed Physical Coordinate and its Applica. tion to Nonlinear Dynamics, Proc. 5th IMAC, Vol. 1, (1987) 300.

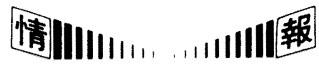

\section{昭和 62 年度エンジニアリング産業の実態と動向}

エンジニアリング振興協会 (理事長・内藤雅喜氏) は, このほど標記の件について 107 社のアンケート調査に基 ついて作成した報告書をなとめた。

概要は次のとおり.

全般的動向=61 年度の受注高は 9 兆 636 億円 (同一企 業ベースでは対前年度比 $1.0 \%$ 減）で依然として低迷状 況を脱していない, 特に国内は 7 兆 4226 億円で対前年 度比 $10.3 \%$ 増となったのに対し, 海外が 1 兆 6409 億 円となったのが主な原因である。この結果, 海外比率は $18.1 \%$ （60 年度は $26.4 \% ） と ， つ い に 20 \%$ 台を割り込 んだ. かつてェンジニアリング産業の成長の糧であった 海外需要が低迷, 内需主導型に転換せざるを得ない状況 となっている.

市場動向と業界構造ニプラント施設別構成比では都 市・社会開発システム, 環境衛生システム, 通信プラン トシステムがシェアを上げ，化学，鉄鋼プラントの低下 が著しい.プラント輸出にかわって内需・情報関連の業 種および分野が伸びている. 62 年度は輸出も若干回復の 兆しが見えるものの, 今後の成長期待分野も内需・情報 関連となろう。

62 年 7 月時点のエンジニアリング事業部門の従業員 数は重厚長大型産業（総合建設などを除くほとんどの業 種）を中心とした雇用調整を反映，10万 9665 人で前年 比 $3.1 \%$ の減となった. 関連会社の設立については新事 業分野進出, 雇用調整をねららた分社型展開が目立ち, 同業界が構造調整過程にあることを裏付けている.

国際化と内需＝円高対策については，「守り」と「攻め」 の二つの側面がある.「守り」は経費削減, 調達品・原材 料の単価切下げ, 人件費の切下げなどである. また「攻 め」の面では選別受注, 第三国調達の拡充, 優位分野で の展開などがある.

また実施済みないし必要とする国際化の施策について
も, もっとも多い回答は第三国調達となっており, 機器・ 資材の海外調達はすっかり定着した感がある.ささらにェ ンジニアリング拠点の設置, 海外企業への下請计発注と い5国際分業関連の施策も2 位になっており, 国際化に 対する意識はかなり高まったといえる。回答から推測す ると海外案件を手掛けることの多い企業の汇とんど (80\%以上) がロ一カリゼーション問題に取り組んでい ることも明らかになった。

一方，エンジニアリング産業が力を入れている内需拡 大分野としては, 環境整備プロジェクト, 特定大型ブロ ジェクト, 都市再開発プロジェクト, 地域開発プロジェ クト, 交通網整備プロジェクト, 電打プロジェクトがあ り, 社会資本, 居住環境の整備を対象としたものが大半 である．特に特定大型および都市再開発プロジェクトへ の注力度は業種の枠を超えた圧倒的なものとなってお り，業種ごとの技術力・営業力を駆使した異業種間協力 を踏まえたビジネスチャンスへの対応が期待される。

課題ニエンジニアリング企業各社の最重視テーマは新 事業分野への対応である. 現在, 進出中および計画中の 新規分野は, バイオテクノロジー関連, 都市再開発関連, 新エネルギー関連が上位 3 分野である. 具体的な閨開事 例としては, (1) 都市再開発・地域開発などのプロジェク ト, (2) ハイテクマテリアル・医薬品などの素材製造業, (3)コージェネレーションなどのェネルギ一関連, また特 徵的なことは各業種とも, ほとんどの新規分野に進出し て㧍り, 今後, 異業種間協力の可能性などが考えられる.

どちらにしても激変する産業社会の中で, 新しい存立 基盤を確立するためにはエンジニアリング産業そのもの の通念を新たにする必要があり, 現在, エンジニアリン グ振興協会で策定中のエンジニアリング産業の中期展望 の完成が期待されている. (服部 敏夫) 